\title{
Gadubanud society in the Otway Ranges, Victoria: an environmental history
}

\author{
Lawrence Niewójt
}

The Otway Peninsula is probably the least known Victorian tribal area, as 19th century records are virtually silent concerning its aboriginal inhabitants.

- DJ Mulvaney, 1961

Nearly 50 years since Mulvaney's archaeological research at Aire River, local historians have ventured little beyond cursory statements regarding the Gadubanud people of the Otway region. Though scholars acknowledge the long-term Aboriginal presence in the area, the dearth of documentary sources has deterred sustained inquiry into the history, economy and enduring relics of pre-contact Aboriginal society. While past attempts at 'ethnohistory' presented surveys of what little information could be gleaned from official papers, to date there has been no attempt to move beyond these brief (but informative) summaries. ${ }^{1}$ Circumventing the perceived roadblock posed by an exhausted documentary record, we can gain a more nuanced understanding of Aboriginal presence in the Otway region by broadening the range of research questions we are prepared to investigate and employing an expanded set of evidentiary materials. A synthesis of the diverse lines of inquiry pursued by archaeologists, earth scientists, ecologists, historians and geographers enables us to gauge the scale and magnitude of past Aboriginal interventions in the landscape. Approaching old sources with a fresh eye for detail and analysis, we can reconstruct the cultural landscape created by the Gadubanud people prior to their disastrous encounter with Europeans in the late 1840s.

The Gadubanud people, residing at various nodes of settlement throughout the Otway region, adapted the land and altered the distribution of ecological communities to best serve their needs. The risks inherent in a subsistence economy were contained and spread geographically using a sophisticated system of land management. Furthermore, a pattern of semi-nomadic movements linked inland, estuarine and coastal occupation sites that were known for their high food yields and provided dietary variety throughout the year. The reconstruction of the Gadubanud's settlement and land use patterns in the Otway region of Victoria - despite the absence of a detailed documentary record - validates Robin and

1 Scarlett 1977: 1-5; Stuart 1981: 79-88; Clark 1990. 


\section{ABORIGINAL HISTORY 2009 VOL 33}

Griffiths' declaration that 'much Aboriginal history is environmental history' and emphasises the potential utility of interdisciplinary approaches in this area of research. ${ }^{2}$

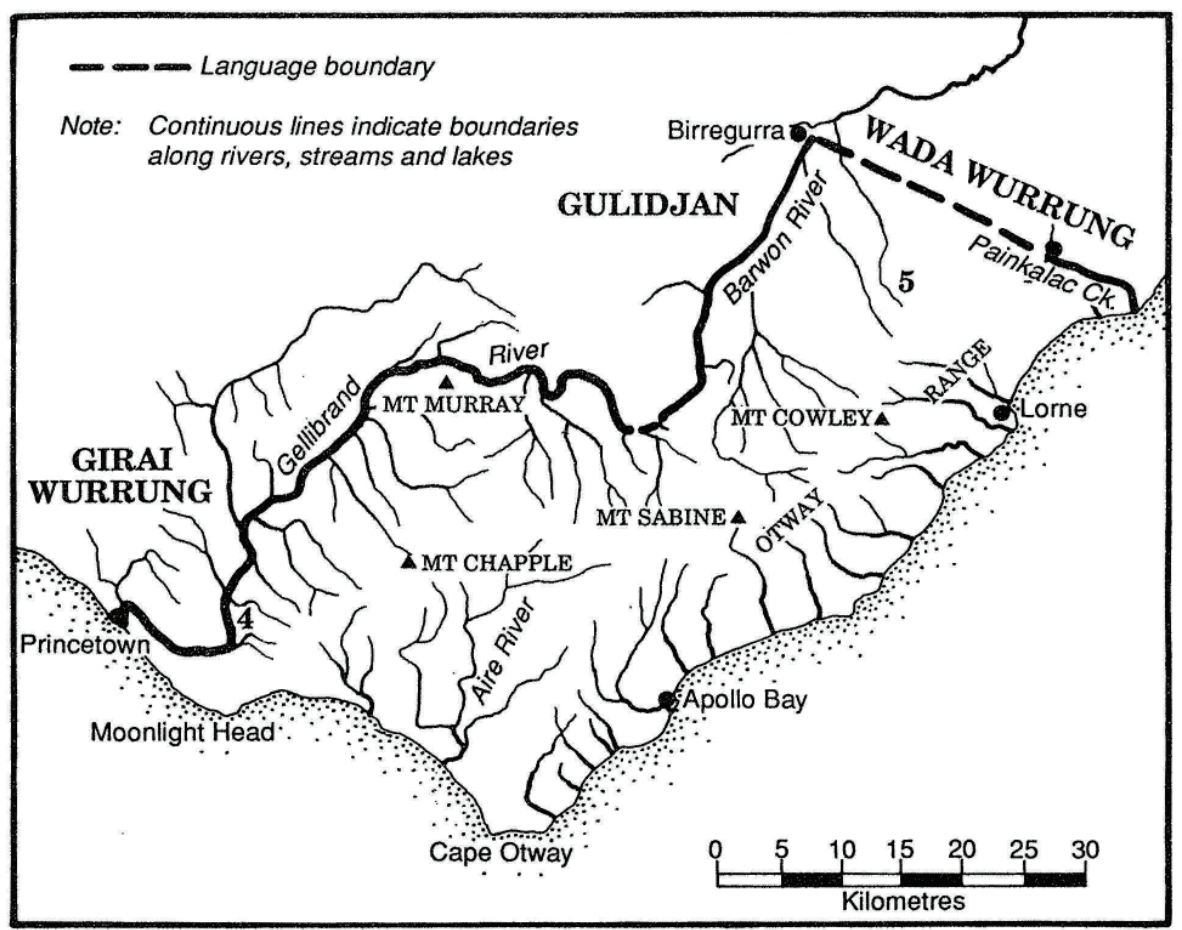

Gadubanud Clans

\begin{tabular}{|c|c|}
\hline No. Clan name & Approximate location \\
\hline $\begin{array}{l}\text { 1. Bangura gundidj } \\
\text { 2. Guringid gundidj } \\
\text { 3. Ngalla gundidj } \\
\text { 4. Ngarowurd gundidj } \\
\text { 5. Yan Yan Gurt clan }\end{array}$ & $\begin{array}{l}\text { Cape Otway } \\
\text { Cape Otway } \\
\text { Cape Otway } \\
\text { North of Moonlight Head } \\
\text { 'Yan Yan Gurt' station, east head of the Barwon River }\end{array}$ \\
\hline
\end{tabular}

Fig 1. The traditional territory of the Gadubanud people and the approximate location of various clans

Source: Clark 1990: 189. Reproduced with the permission of Professor Ian D Clark.

2 Robin and Griffiths 2004: 456. 


\section{The Gadubanud people in the written record}

Hemmed in by a rising ocean that stabilised about 7000 years ago, the uplifted sedimentary rocks of the Otway Range run from north-east to south-west at an elevation of about 500 metres above the sea. A few isolated peaks reach up to 675 metres, and at many points along this coastline bare mountains and treeclad ridges plummet dramatically into the sea. ${ }^{3}$ In the north, the narrow belt of foothills merge with the undulating volcanic plain that is the definitive feature of Victoria's Western District. Littoral plains are found only at Apollo Bay and further west, but even these flat stretches of coastal terrain do not exceed five kilometres in width. Vegetation within the traditional territory of the Gadubanud people varies from heath on the sea cliffs, to dunes near the Cape, open forest on the eastern slope, wet sclerophyll forest in the mountains and tracts of rainforest along some watercourses and mountain gullies (see Fig 1). Highly productive ecosystems, such as the wetlands found at the base of the northern foothills (at the headwaters of the Barwon River) and the numerous river estuaries of the coastal zone, provided a vast food supply and a range of options regarding the seasonal sequence, frequency and intensity of harvesting.

Although they were rarely recorded beyond their country, the Gadubanud maintained complex ties with other Aboriginal groups and were known to have close linguistic and familial connections with their northern neighbour, the Gulidjan people of the Lake Colac area. ${ }^{4}$ They avoided the primitive sheep stations that rapidly spread across the volcanic plains of the Western District after 1837, and shunned the company of heavily-armed European settlers. As a result, comparatively little is known about their social organisation, leadership, customs, language and traditions. What follows is a brief summary of what the documents tell us about these people.

The modern name given to these people derives from the work of James Dawson, who recorded the Cape Otway language group as 'Katubanuut' and claimed that this meant 'King Parrot language' in the local dialect. ${ }^{5}$ These people were closely associated with the Gulidjan who resided in the vicinity of Lake Colac, but were considered to be 'wild blacks' by both the Wathaurong to the north-east and the Girai wurrung to the west. ${ }^{6}$ Their presence was first recorded by Chief Protector Robinson in 1842 when he met three Gadubanud people at the mouth of the Hopkins River (near present-day Warrnambool) and received details of four clans that resided on the western edge of the Otway Ranges: three lived at the Cape Otway peninsula and one was said to reside north of Moonlight Head. ${ }^{7}$ One of these clans was said to belong to Bangurer, which was noted as the local place-name referring to Cape Otway. ${ }^{8}$ Later that year, an unconfirmed report blamed the Gadubanud for the removal of food and blankets from an

3 Gill 1978: 67-75.

4 Le Griffon 2006.

5 Dawson 1881: 2.

6 Addis cited in Clark 1995: 119.

7 Clark 1990: 190-191.

8 Robinson cited in Clark 1990: 190. 
outstation, and in 1844 they were suspected of killing 'a white teenage boy'. ${ }^{9}$ In 1853, a letter from George Armytage to Superintendent La Trobe identified a fifth clan associated with the Gadubanud people. The 'Yan Yan Gurt tribe' was said to reside at the east head of the Barwon River, 12 miles south-east of Birregurra, near the base of the Otway Ranges. ${ }^{10}$

Dawson also noted that the Gadubanud residing at Cape Otway were linguistically affiliated with the Djargurd speakers of the Warrnambool area. ${ }^{11}$ Their meeting with Robinson - which took place over 50 kilometres beyond the western boundary of their traditional territory - is the only confirmed record of the Gadubanud people beyond their homeland. With respect to the great meetings held in the Western District near Caramut, Dawson noted that 'None of the sea coast tribes attended the meetings at Mirraewuae, as they were afraid of treachery and of an attack on the part of the others' ${ }^{12}$

This level of insularity was highly unusual in Victoria, where trade links and marriage ties amongst Aboriginal groups were known to span hundreds of kilometres. On 2 April 1846 Superintendent La Trobe, on his third and final attempt to reach Cape Otway, met with seven Gadubanud men and women in the valley of the Aire River before trekking across the open grasslands to his destination. ${ }^{13}$ Also in April 1846, the squatter Henry Allan made an unsuccessful attempt at a north-south crossing over the mountains, guided by two Aboriginal women from the Wesleyan mission at Buntingdale. In the northern foothills of the Otway Ranges, on the upper reaches of the Gellibrand River, he found an unoccupied Aboriginal camp. On his return trip through the area, he revisited this site and found a large number of implements that had not been there before. ${ }^{14}$ At Cape Otway, in July and August of 1846 the contract surveyor George Smythe encountered a group of Aborigines consisting of one man, four women and three boys. ${ }^{15}$ They killed a member of his surveying party, and in late August 1846 Smythe returned to the area on a retaliatory expedition with a retinue of several Wathaurong warriors from the Geelong area. Armed with muskets and tomahawks, Smythe and the group came across seven Gadubanud at the mouth of the Aire River, which they attacked and killed. ${ }^{16}$ After this August 1846 massacre, a final note regarding the Gadubanud people appears in the colonial press. On 4 January 1848 an article in the Geelong Advertiser reported a conflict

9 Horton 1994: 397.

10 Armytage in Bride 1898: 175.

11 Dawson cited in Scarlett 1977: 2.

12 Dawson 1881: 3.

13 Blake 1975: 18.

14 It is suspected that the tools found by Allan were manufactured at a set of 'grinding rocks' found on Lardner's Creek, one mile upstream from its junction with the Gellibrand River. There, the basalt of the volcanic plains forms large outcrops near slabs of sandstone that had been exposed by the rushing water, and the grooves on its surface signify its importance as a site of production where basalt 'blanks' were manufactured into sharpened axe heads that could be used or traded. See Massola 1962: 66-69.

15 Clark 1995: 119.

16 Geelong Advertiser, 29 August 1846, 'The Late Slaughter of the Cape Otway Blacks'. 
between two Aboriginal groups near Port Fairy. Two men were killed in the attack, among them 'a man who belonged to the Cape Otway tribe, the last of his race'. ${ }^{17}$

These chance encounters with the Gadubanud people point toward an extremely low resident population in the Otway region at the time of contact. No more than eight members of this language group were ever seen together at one time, and the sum of all recorded individuals would yield a total number of 26 people $(3+7+8+7+1)$. This total indicates a remarkably tiny group size for a vast territory stretching from Painkalac Creek (near Aireys Inlet) in the east to the Gellibrand River that flows west of the mountains. With over 100 kilometres of coastline yielding shellfish, the presence of several wetlands and productive estuaries, and the plant foods available both in open land and potentially acquired through trade with neighbouring groups, it would be reasonable to suspect that the region's 'carrying capacity' would have encouraged the flourishing of a far greater population. Evidence from the archaeological record, historic coastal survey maps and an assessment of regional food resources suggest that the pre-contact population of the Gadubanud was far larger than indicated in the documentary record. These alternate sources of evidence point to the existence of a sophisticated resource management regime and movement corridors that were maintained through the selective deployment of fire to generate a specific type of landscape mosaic. While it is impossible to produce a precise figure for the historical population of the area, a survey of the potential food supply suggests that, rather than the 'tens' of Gadubanud people recorded in historical documents, we should begin to adjust our thinking to accommodate the 'hundreds' that once lived in the Otway region.

\section{Regional food resources}

Under the management of the Gadubanud people, the Otway region yielded a food supply that was diverse, conveniently accessed and organised in a flexible manner so that surplus, rather than scarcity, was the norm. In general, spring and summer were the seasons of greatest abundance, while winter was the leanest season. The ability of Aboriginal society to make full use of nature's bounty was noted by James Dawson, finding that in western Victoria 'Articles of food are abundant, and of great variety for everything not actually poisonous or connected with superstitious beliefs is considered wholesome'.$^{18}$ As a result, differences in taste and cultural approaches to sustenance need to be kept in mind when considering the carrying capacity of Australian environments and the efficacy of various land management regimes.

17 Geelong Advertiser, 4 January 1848, 'The Blacks'.

18 Dawson 1881: 18. 


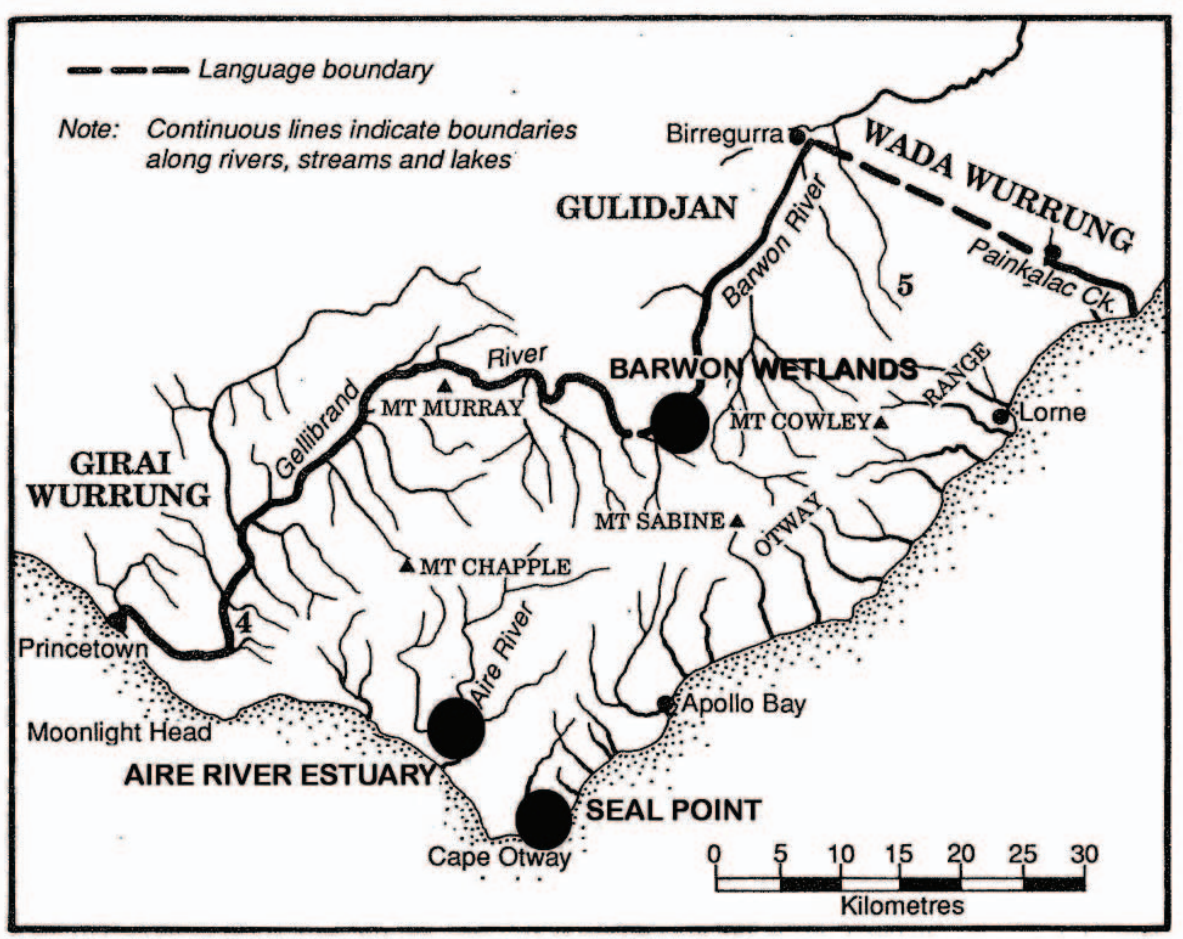

Fig 2. Major settlement nodes of Gadubanud society

Wetlands, such as those found near the outlets of the Gellibrand and Aire rivers, provided a fine variety of foods. Fish, eels, waterfowl and bird's eggs added much protein to the diet yet responded to exploitation with a high rate of annual regeneration. ${ }^{19}$ In the region's lakes and wetlands, particularly those at Gerangamete, Irrewillipe and Chapple Vale, food was reliable and easily accessed. Some reports from the Western District noted the means by which wetland foods were procured. Dawson was told that 'Swans are killed in marshes, by the hunter wading among the tall reeds and sedges, and knocking the birds on the head with a waddy'. ${ }^{20}$ Clark and Heydon's work on Aboriginal placenames confirms the importance of waterfowl in local diet. Their dictionary lists the Aire River estuary's Gadubanud name as Gunuwarra, which translates to mean 'swan' ${ }^{21}$ Fish were commonly caught at night, the technique being that 'A fire is lighted on the bank, or a torch of dry bark held aloft, both to attract the fish and give light'.22 Consumption patterns could be adjusted to favour foods that were 'in season', thereby conserving resources that had become scarce or were

19 Lourandos 1980: 249.

20 Dawson 1881: 93.

21 Clark and Heydon 2002: 92. Further study of archival materials may yield additional insight and, potentially, a salvage grammar and wordlist similar to recent work completed in the Hunter River and Lake Macquarie areas of New South Wales. See Lissarrague 2006.

22 Dawson 1881: 95. 
in a state of recovery. The abundance of eels in local marshes, found both on the coast and in the northern foothills of the Otway Ranges, would have meant that the Gadubanud people had no need to join other tribes for the corroborees that took place at the Western District lakes during the autumn season eel harvest.

Fishing in the tidal estuaries could also produce a substantial protein source, an ideal supplement to the large volume of starchy tubers growing in the shallows and at the water's edge. Species such as water-ribbons (Triglochin procera), the club-rush (Scirpus maritimus), and the rhizomes of the tall spikerush (Eleocharis sphacelata) were commonly found throughout the region and provided decent nourishment. ${ }^{23}$ The water-ribbon could be found in the swiftflowing streams on the Otway coast, in lakes, swamps or floodplains. Plants can yield over 200 starchy tubers, with each root up to $5 \mathrm{~cm}$ long and weighing 0.5$2.5 \mathrm{~g} .{ }^{24}$ The attraction of the Gellibrand and Aire River estuaries was heightened by their sheltered topography, and at the same time they were located within easy walking distance of the ocean. At these sites, a diet of starchy plant foods could be combined with animal protein unique to freshwater and marine environments without requiring elaborate group movements. At Aire River, archaeologists found that molluscan remains of larger intertidal marine species and freshwater mussels were present along with the remains of parrot-fish, more extensive 'indeterminate fragments of fish', and snails. ${ }^{25}$

William Buckley's memoirs provide a detailed set of observations on the use of some Otway wetlands. On one of their wanderings in south-western Victoria, Buckley's mob was invited to take part in an exchange of tuber roots for eels. The groups were to meet at a place called Bermongo. ${ }^{26}$ Located at the headwaters of the Barwon River, the marsh was teeming with eels. When they arrived for the exchange, prepared with woven baskets full of starchy tubers, they found a large congregation of about 80 men, women and children. ${ }^{27}$ Though Buckley does not name the group involved in the exchange with his Wallarranga mob, it is very likely that they were dealing with the Yan Yan Gurt clan, the only clan of the Gadubanud people known to live on the north side of the range. ${ }^{28}$ The exchange emphasises the long-distance character of trade connections in the Aboriginal economy and the strong desire for dietary variety. This event also bolsters Dawson's claim that many varieties of fish were part of the Aboriginal diet and that the tuupuurn eel was 'reckoned a very great delicacy'. ${ }^{29}$

Several kilometres to the north of this site, Buckley experienced threat of attack when his group stayed at the Gerangamete swamp. In his description of

23 Scarlett 1977: 3.

24 Gott 1982: 62.

25 Mulvaney 1961: 3-7.

26 There is a high probability that this site was located near the present-day community of Barramunga, in the area now flooded by the West Barwon reservoir. See Clark and Heydon 2002: 25.

27 Morgan 1852: 66.

28 Armytage in Bride 1898: 175.

29 Dawson 1881: 19. 
this incident, in which it is clear that the group had resided at the swamp for some time without invitation or permission, he stated that his mob was threatened with attack in a night-time ambush but managed to flee safely. Though he did not give a name for the group that forced them away from the wetlands, the level of fear communicated in his account suggests that these fierce protectors of the marshes had a history of hostility with his mob.

Fleeing the scene of their illegal squatting, they covered several kilometres in the darkness of night and reached the top of Sugarloaf Hill within a few hours. ${ }^{30}$ This movement rate indicates that open forests covered this part of the range and that fire was regularly deployed to clear undergrowth. It is likely that this trail was originally blazed by the Gadubanud and was similar in form to the 'native path' taken by La Trobe in 1846 from Moonlight Head up into the forested mountains. ${ }^{31}$ Burning would clear ground and help establish the gaps in the canopy that was necessary for navigation by moonlight. The presence of burnt and unburned tracts, characteristic of a landscape mosaic within the Otway forests, is further evinced in Buckley's account. From Sugarloaf Hill, with a good view of the coast, the group split into two and Buckley led his cohort to a place near the seaside which he called Kirkedullim. While only a few hours were required to travel from the swamp to the main ridge of the coastal range, the trek to the sea required them to wander for several days until they made a lengthy halt at his favoured spot on Painkalac Creek. Enjoying the warm summer weather on the coast, Buckley noted that the group had access to plenty of freshwater and sustained themselves by catching fish. ${ }^{32}$ The windward side of the eastern Otway Range, especially the elevated, wetter areas, possessed no signs of being subjected to frequent burning. For the Gadubanud, this was the remote edge of their territory.

The rock platforms of the Otway coast also proved to be an important food procurement zone, allowing access to shellfish at low tide. Even today, heaps of deposited shells persist as lasting reminders of Aboriginal food harvesting, and these middens are occasionally found in close proximity to tidal estuaries. At Seal Point, located on Cape Otway peninsula, archaeologists discovered 'all the features of a semi-sedentary seasonal (warm weather) base camp' ${ }^{33}$ Across Bass Strait, on a similar stretch of coastline in northern Tasmania, research has shown that 'Shellfish contributed about half the total flesh weight throughout the whole occupation'. ${ }^{34}$ Though shellfish alone could not make up a diet, such an easily obtained source of protein added variety to food consumption patterns and could be relied upon as the main source of nutrition at certain points in the year. ${ }^{35}$

30 Morgan 1852: 121.

31 Blake 1975: 18.

32 Morgan 1852: 122.

33 Lourandos 1980: 250.

34 Flood 1989: 179.

35 Meehan 1982: 31-39. 
However, food procurement in the coastal zone had distinct seasonal limitations. In the years prior to European settlement in western Victoria, William Buckley spent considerable time living on the coast near present-day Aireys Inlet. He found that his exposed hut on the coast was subjected to 'dreadfully cold and tempestuous' weather in winter and that the shellfish supply became very scarce and difficult to collect during this period. ${ }^{36}$ Environmental scientists have noted that the rough weather and huge swells characteristic of the Southern Ocean in winter would have made food harvesting in rock pools and ledges a dangerous task with a very low probability of success. ${ }^{37}$ The food scarcity experienced by Buckley during winter compelled him to migrate inland. Episodic shifts away from the coast would have allowed natural regeneration of the food resource, ${ }^{38}$ minimised the environmental impact of shellfish harvesting, and satisfied a strong desire for dietary variety. ${ }^{39}$ A journey over the mountains to the Barwon River eel marshes would have been a sensible response to the onset of seasonal change. Wintering on the leeward slopes of the northern foothills posed many advantages, not the least being the abundant timber available for the perpetual campfire.

Beyond marsupials, the Gadubanud exploited a wide range of animal protein sources. These included: native rats and mice, snakes, lizards, frogs, birds and their eggs. ${ }^{40}$ Possums provided sustenance in addition to a fur pelt that could be fashioned into a warm cloak. Hunting was most easily performed at forest edges largely due to the combination of good visibility, adequate cover in the re-growth vegetation, and proximity to the habitats of the pursued game. These factors would encourage attempts to burn out patches and establish a well-indented forest perimeter that maximised edge spaces. In general, the forests were less suitable environments for the pursuit of game as undergrowth reduced visibility, hampered movement and established barriers that could interfere with thrown spears. These factors severely constrained the utility of wet sclerophyll forests as a food procurement zone. ${ }^{41}$ With regard to hunting in areas along the sea coast, the presence of a rich marine mollusc food resource provided incredible flexibility in the frequency and intensity of game hunting so that this activity was guided by taste and dietary choice rather than absolute necessity. In the more open woodlands of the northern foothills, a completely different set of game animals could be found, including: eastern grey kangaroo, red-necked wallaby, common brushtail possum, sugar glider and fat-tailed dunnart. ${ }^{42}$

Vegetables were a crucial component of the food supply. In western Victoria, plant foods were known to have comprised at least half of the diet. Crops of tuber

36 Morgan 1852: 36.

37 Gill 1976: 31-39.

38 Mannino and Thomas 2002: 467.

39 At Seal Point, evidence shows that dietary variety was provided in situ, with the remains of seals, possums, wallabies, and fish found at the middens alongside a large number of 'sandstone pestle-mortar type' tools used for pulping plant fibre. See Bowdler and Lourandos 1982.

40 Flood 1989: 90.

41 Scarlett 1977: 4.

42 Richards 1998: 7. 
plants such as the murnong yam (Microseris lanceolata) were maintained through landscape burning. This yam could grow in forest clearings and was favoured by Aborigines because of its sweet, milky, coconut-like flavour. Although physical transplant from one site to another could be performed, the wind-borne seed was known to colonise clear ground. The activity of digging for roots aerated soil patches and encouraged further seed germination. ${ }^{43}$ In Victoria we find 218 species of edible roots that could have been incorporated into the Aboriginal diet. High in carbohydrates and available year-round, the root crops grow in dense clusters so that 'a large amount of food can be collected in a relatively small area'. ${ }^{44}$ This spatial concentration poses a problem for researchers: small yam patches and the process of harvesting could go unnoticed in the documentary record. Residing on the Bellarine Peninsula, William Buckley mentioned that there were long periods when his mob subsisted almost entirely on roots dug up by the women, while 'men procured opossums occasionally' ${ }^{45}$ Readily available and encouraged by the burning of clearings, in the eastern Otways tuber and yam patches were known to occur along corridors frequently travelled by Buckley's Wallarranga mob.

The signs of yam cultivation may still be witnessed in the region today. Following the 'Ash Wednesday' fire of February 1983 at Anglesea, in the spring local residents witnessed 'a phenomenal flowering of tuberous perennials'. ${ }^{46}$ By contrast, nearby unburnt areas exhibited quite sparse flowering of perennials. A ten-year study of recovery from this fire showed that most of the flowering species were herbaceous, and these declined in the following years as the forest regrew and the canopy closed. ${ }^{47}$ Subject to systematic burning in the past, the maintenance of these herbaceous species for food would have required burning at three-year intervals to hold the forest in an arrested stage of fire recovery and ensure an optimal supply of starchy tubers. ${ }^{48}$ In this way, fire deployed in the eucalypt woodland of the eastern Otways established a multifunctional landscape. ${ }^{49}$

Burning maintained the open structure of the forest, allowing continued use of the movement corridor in addition to ensuring good yields of vegetable crops. Furthermore, this flexible system of land management could easily accommodate changes in population by altering fire frequency and physically enlarging yam fields. The tending of herbaceous plants in this manner ensured that foods could be harvested and consumed without the need for storage facilities, and the patchy landscape pattern possessed characteristics that were also conducive to

43 Gott 1982: 64-65.

44 Gott 1982: 60.

45 Morgan 1852: 47.

46 Gott 2005: 1205.

47 Wark 1996: 121-141.

48 The herbaceous species which were staple foods on the Basalt Plains, located northwest of the Otway region, were also known to require frequent burning in order to maintain a maximal food supply. Tussock grassland (Themeda sp.) unburnt for three years provides few gaps on which non-grass plant species can germinate or thrive. See Stuwe 1994: 93-95.

49 McKenzie and Kershaw 1997: 566. 
game hunting. Fresh re-growth after a burn enticed animals to graze the open paddocks, while the interspersed visual barriers, aural suppressants, and ease of pedestrian mobility worked to the advantage of the hunter.

Although the thick forests were associated with a scarcity of food and the difficulty of its procurement, even there the Gadubanud could find something good to eat. While the closed-canopy rainforest complex offered little food, the more extensive wet eucalypt forests were markedly more productive. Indeed, though drier climatic conditions since about $4300 \mathrm{BP}$ encouraged a shrinking of the rainforest complex and concomitant expansion of the eucalypt communities, this differential productivity could have motivated Aboriginal burning and the hastening of localised transitions. Ashton's long-term study of the mountain ash (Eucalyptus regnans) in central Victoria sets out several positive qualities of the wet sclerophyll forest complex. Older stands would suppress undergrowth - easing movement and increasing visibility - and encourage the growth of ferns that could act as a habitat for game, particularly wallabies. ${ }^{50}$ The pith of bracken fern (Pteridium esculentum Forst.) was also edible. Studies have found it to possess a higher carbohydrate content than the potato, and so the harvest of this resource may have prompted specific trips into the forest. ${ }^{51}$ This foodstuff would have been a convenient source of nutrition for journeys across the mountain range and expeditions into the forest in search of the raw materials needed for the manufacture of trade goods. The discovery of pulping tools at the Seal Point archaeological site suggests that the Gadubanud residing there made intermittent use of tree ferns as a source of carbohydrates. ${ }^{52}$

The land-based economy of the Gadubanud people was predominantly geared toward the procurement of foodstuffs that would sustain their society. Lacking many of the conceptual constraints that limit the modern-day diet, the Gadubanud found sources of nutrition in many types of environments that make up the Otway region: coast, wetland, estuary, forest and grassland. Ongoing adjustments in the timing and intensity of harvests provided for the long-term sustainability of food resources, and the lack of dependence on any one particular food allowed a dynamic society to cope easily with the vagaries of climate and mitigate against risk of resource failure. The skilful deployment of fire encouraged the development of a complex landscape mosaic that arranged resources in a convenient manner, replenished root crops and opened up the movement corridors that linked cultural points of interest. Under Aboriginal management, the Otway region could yield enough food to sustain a population that numbered in the hundreds.

50 Ashton 1976: 397-414.

51 Gott 1982: 64-65.

52 Bowdler and Lourandos 1982 


\section{Settlement distribution, communication corridors and landscape burning}

Given that the Gadubanud economy was overwhelmingly focused on feeding its population and not the production of trade commodities, the investigation of regional food resources has helped confirm the existence of three important settlement concentrations in the Otway region: the Aire River estuary, Cape Otway and the wetlands found along the Barwon River. The locations of Gadubanud camps noted by George Augustus Robinson, William Buckley, and George Armytage exhibit a tight correlation with highly productive food procurement zones and significant archaeological deposits (see Figs 2 and 3).

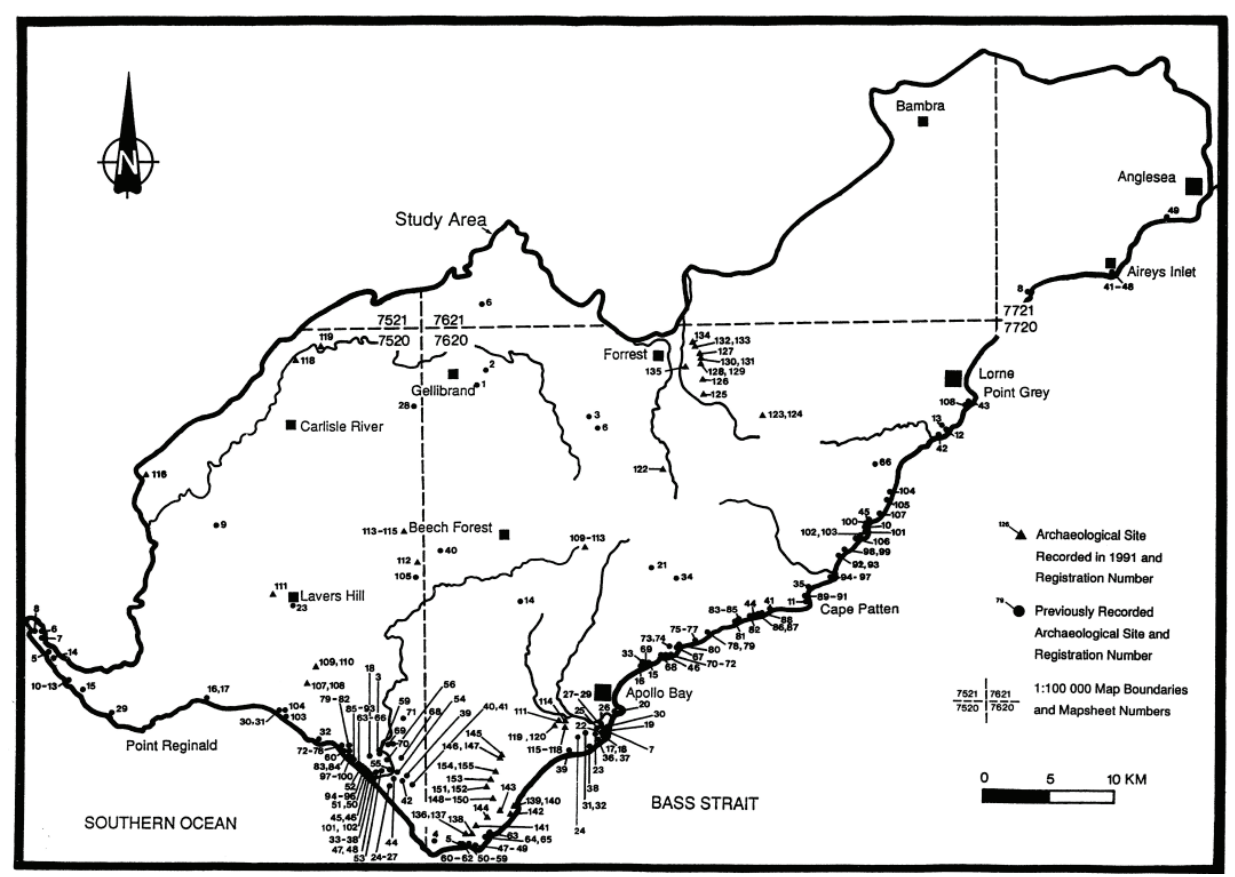

Fig 3. Distribution of archaeological sites in the Otway region

Source: Richards 1998: 36. Reproduced with the permission of Aboriginal Affairs Victoria.

An archaeological study, released in 1998, encompassed the Otway Ranges and the entirety of the Gadubanud territorial area..$^{53}$ In total, 276 Aboriginal archaeological sites were recorded in the study area. . 'Archaeological density', corresponding to the number of artefacts found per square kilometre, was calculated to be highest at a distance less than five kilometres from the ocean,

53 The latest survey report addressed the fact that there had been 'little systematic archaeological study within the Otway area as a whole'. All previous findings were compiled into a single dataset and supplementary fieldwork was completed to address spatial gaps in coverage. See Presland 1982: 4.

54 Richards 1998: xiii. 
whereas the mountainous zone (containing the wet sclerophyll forest and cool temperate rainforest) was found to have the fewest occupation sites..5 PreEuropean population distribution was summarised in the following statement:

Late precontact period Aboriginal occupation of the Otway Range appears to have been concentrated on narrow strips along the peripheries of the Range. The central core of the range, including the upper slopes and the plateau, was also visited and exploited by Aboriginal populations but on a much lesser scale than the ecotonal peripheries. ${ }^{56}$

Most archaeological sites mentioned in the study contain stone artefacts or flaked stone implements. Flint artefacts, which could only have been produced at a few known coastal locations, are usually found within three kilometres of the ocean. At Aire River, Mulvaney found hundreds of stone chips, flakes and artefacts in two rock shelters. The overwhelming majority of these were made of flint, likely sourced from the 'irregularly shaped nodules of flint cast on the beach' near Cape Otway. ${ }^{57}$ The latest archaeological study identified two additional sites where flint artefacts were found on the northern side of the Range, approximately 18 kilometres inland, near the present-day community of Forrest. ${ }^{58}$

The discovery of flint artefacts, of coastal provenance, near the headwaters of the Barwon River (East Branch), suggests the existence of a trans-Otway movement corridor. This track linked the people of the coast with their brethren at the northern wetlands, a food harvesting zone so important that it once attracted Buckley's mob from their distant base on the Bellarine Peninsula. ${ }^{59}$ While the discovery of artefacts made from coastal flint suggests a northward direction of travel, there is little doubt that a track kept open by frequent burning would encourage traffic in both directions.

The route chosen for this trans-Otway track would have deliberately expedited the process of crossing the mountains in order to minimise the length of the journey and its physical strain on the traveller. The main ridge of the Otway Range receives an average annual rainfall in excess of $1800 \mathrm{~mm}$, with 60 65 per cent of this precipitation falling in the May-October period..$^{60}$ Scheduled to coincide with the eel harvest, an autumn crossing of the mountains had a high probability of experiencing rain. This would make for a cold, wet journey from the coast to the marshes, and so a winding track would be both impractical and highly undesirable. For the Gadubanud, this forest landscape was also imbued with superstitious significance for it was said to be the domain of spiritual beings, and known for its roving packs of wild dingoes. ${ }^{61}$ These considerations,

55 Richards 1998: 49.

56 Richards 1998: 63.

57 Mulvaney 1961: 1.

58 Richards 1998: 40.

59 Morgan 1852: 66.

60 Linforth 1977: 61.

61 Dawson 1881: 89. 
as well as the need to account for the movement barriers found in the Otways - dense undergrowth, steep topography, enormous fallen trees, leech-infested forest gullies, incessant rains and thick mud - worked to channel traffic to only a few possible routes.

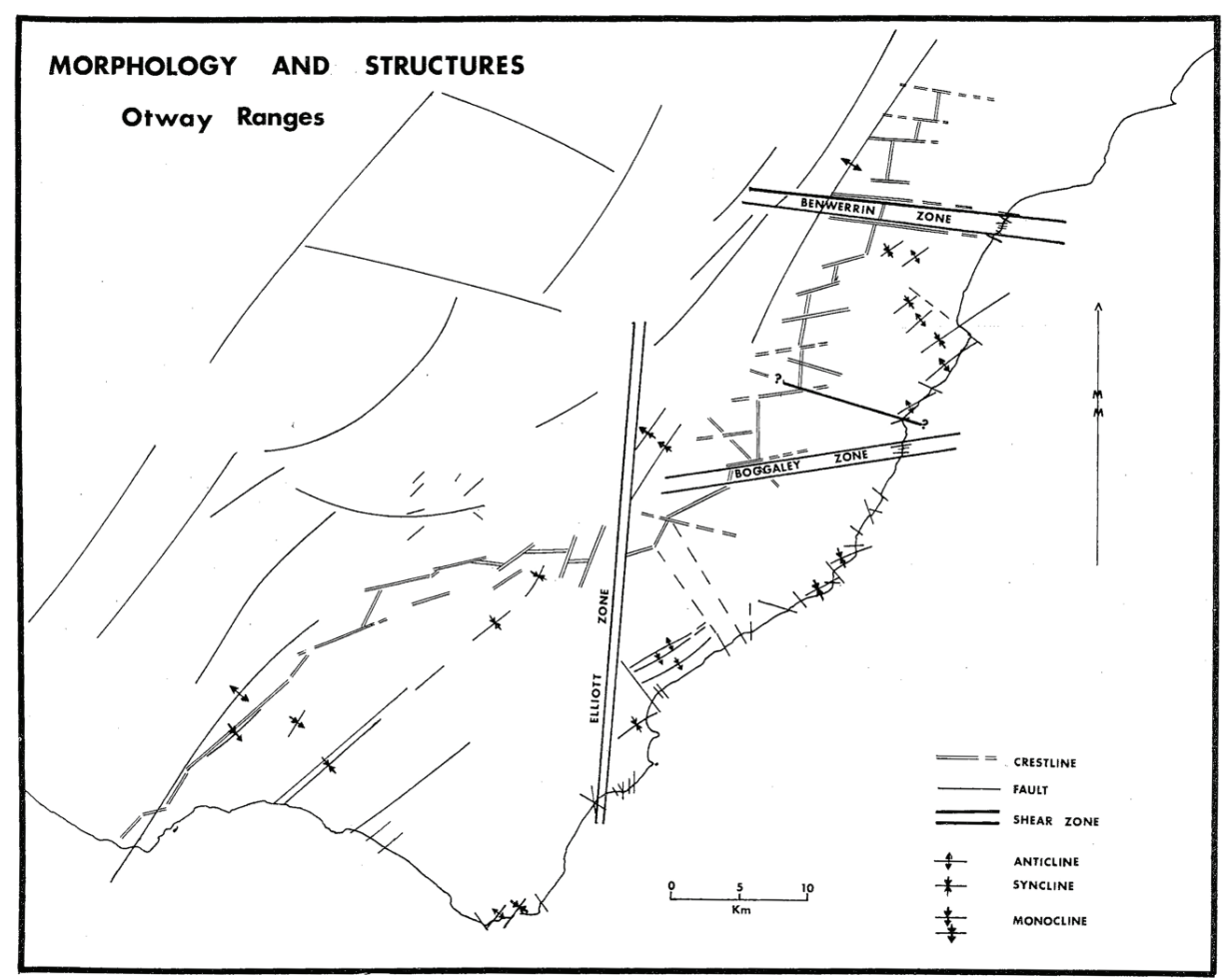

Fig 4. Running north-south, the Elliott Zone is characterised by a series of parallel valleys that would have provided the most direct route over the Otway Range

Source: Medwell 1977: 29. Reproduced with the permission of the Royal Society of Victoria.

An examination of topographical data alongside studies of regional geomorphology offers several potential north-south routes over the mountains. Of prime significance is the 'Elliott Zone', a geological shear zone that transcends the main ridge of the Otway Range in a north-south alignment (Fig 4). This zone is marked by a series of parallel valleys (and watercourses) on the coastal face of the range and, on the north side, the relatively straight trough followed by the Barwon River as it flows across the volcanic plain. ${ }^{62}$ From the coast, following Skenes Creek, Wild Dog Creek or the east branch of the Barham River (west of Apollo Bay) would allow pedestrians to reach the top of the main ridge directly. Regardless of the valley used in the ascent, once atop the ridge the trekkers

62 Medwell 1977: 28-30. 
would need to aim toward Mount Sabine and, just before reaching the pinnacle, they would veer northward once more and descend toward the Barwon River valley along the back of a spur ridge. Marching down this ridge, the Gadubanud would reach a point requiring the crossing of a stream. Only two kilometres beyond the ford they would find the first eel marsh at the headwaters of the Barwon, the Bermongo recorded in Buckley's memoir.

But which route did they take? The Barham River valley route would have been an unlikely choice for pedestrian traffic due to the greater (east-west) distance covered and the steep nature of the final ascent to the ridge. The gentler ascent and shorter length of the Skenes Creek and Wild Dog Creek routes made them significantly more appealing, and the watercourses marking these paths were easily accessed from the coast. Nearly identical in distance and structure, either one of these routes could have been used by the Gadubanud. However, evidence dating from the start of European occupation in the region suggests that Wild Dog Creek was the favoured route over the Otways.

At the end of the 1840s, when William Roadknight came to establish a cattle run on Cape Otway peninsula he crossed the mountains using the valley of Wild Dog Creek and made the remainder of his journey westward along the coast. William and his son Thomas expended a great deal of effort widening this track into a 'good sound Dray Road'. In a letter to Superintendent La Trobe, Roadknight described the process of discovering and cutting this route. He acknowledged that their success was directly dependent on 'the local knowledge acquired by my son during this arduous undertaking'. ${ }^{63}$ The Gadubanud people also maintained the coastal movement corridor, as landscape burning between Apollo Bay and Seal Point had established easily-traversed grass and heath vegetation on the undulating hills that lead to Cape Otway.

In March 1849, Superintendent La Trobe used a track to cross the Otway Ranges and reach the sea at a point east of Apollo Bay. Although he did not specify, it is most likely that he followed the Wild Dog Creek track charted by Roadknight only a few years earlier. He noted:

It is a rough track, but still it is one, -50 miles wholly in the forest, a basin in the higher portion of the range $12 \mathrm{~m}$. through, - is entirely filled with

Fern Trees of great beauty. ${ }^{64}$

This movement corridor could only have been opened with the systematic blazing of the trail. The rough state of the track reported by La Trobe highlights the prolonged absence of fire: vigorous undergrowth had begun to fill in the open spaces.

The discovery of a vast area of fern trees in an elevated portion of this highrainfall region gives a sense of the vegetation change initiated by landscape burning. Fern trees tend to establish themselves in clearings and may grow quite

63 Letter of William Roadknight to CJ La Trobe, reproduced in Parkinson 2005[1863]: vii.

64 Blake 1975: 36. 
thickly along forest edges. Their proliferation atop the mountains would have required the removal of any pre-existing closed canopy forest cover, likely the rainforest complex marked by the myrtle beech tree species. The ferns would then take over these discrete clearings or form the understory beneath an opencanopy eucalypt forest community. La Trobe's description of the 'entirely filled' basin omits mention of tree cover, suggesting that either the area was devoid of trees or that the coverage was not particularly significant. In the Otway Ranges, both the myrtle beech and mountain ash trees could grow up to be imposing giants with trunks several metres in diameter - the type of forest feature that tends to elicit commentary - and so the lack of comment about this aspect of forest structure gives a strong indication that the vegetation communities had been transformed through the deployment of fire. A decade earlier in Tasmania, George Augustus Robinson remarked on the fern trees found in areas recently burnt by Aborigines and noted their abundance along a 'direct road for the natives' that led to the Tamar River. ${ }^{65}$ Most certainly, the proliferation of fern trees La Trobe found atop the Otway Range did not get there by accident.

On the coast, we can gauge the effects of Aboriginal fire use and land management practices from a survey map produced by George Douglas Smythe in 1846. Created in preparation for the lighthouse construction project at Cape Otway, Smythe chronicled the vegetation and forest communities found along the coast, documenting a cultural landscape that had been transformed by the fire-stick (Fig 5). The large timber forests had been left to occupy the highest, most inaccessible terrain whilst the frequent pedestrian traffic between Cape Otway and the Aire River was eased by the removal of heath scrub and its replacement by grass cover. In such a zone of good soil, high rainfall and proximity to vigorous forests, the appearance of grassland and the stark boundary with the forest signals that this landscape mosaic was shaped and kept in place by the regular application of fire to the land. By manipulating the seasonal timing, intensity and frequency of fire deployment the Gadubanud people were able to reconfigure vegetation communities and structure a landscape that fulfilled their needs for sustenance and unhindered mobility along high traffic corridors.

More information regarding the application of fire to the region's forests has recently emerged from the study of sediment core samples taken at Chapple Vale, Aire Crossing and Wyelangta. The data collected from swampy patches at Aire Crossing (near the top of the Aire River basin) and Wyelangta were both found to be in the midst of cool temperate rainforest stands that have experienced little significant change from roughly 9000 years BP. ${ }^{66}$ Largely unmanaged by fire, both sites possessed low charcoal readings. At Wyelangta, scientists found such floristic stability that they believed 'the site may be the first identified glacial refugium for rainforest in Australia' ${ }^{67}$ The sediment record from Chapple Vale, a swamp site located on the western slope of the Otway Range, exhibited a sudden and sustained rise in charcoal levels from around 2500 BP. Researchers

65 Gammage 2008: 251.

66 McKenzie and Kershaw 2000: 177-193, 2004: 281-290.

67 McKenzie and Kershaw 2000: 189. 
concluded that the 'substantial increase in charcoal' must have been the result of frequent fire and that this 'may have had substantial influence on the vegetation from this time' ${ }^{68}$ However, the appearance of so much charcoal in the sediment record was not attributed to Aboriginal fire management. Instead, the authors of this study maintained that climate was 'a major controller of vegetation change to sclerophyll communities' at this site. ${ }^{69}$

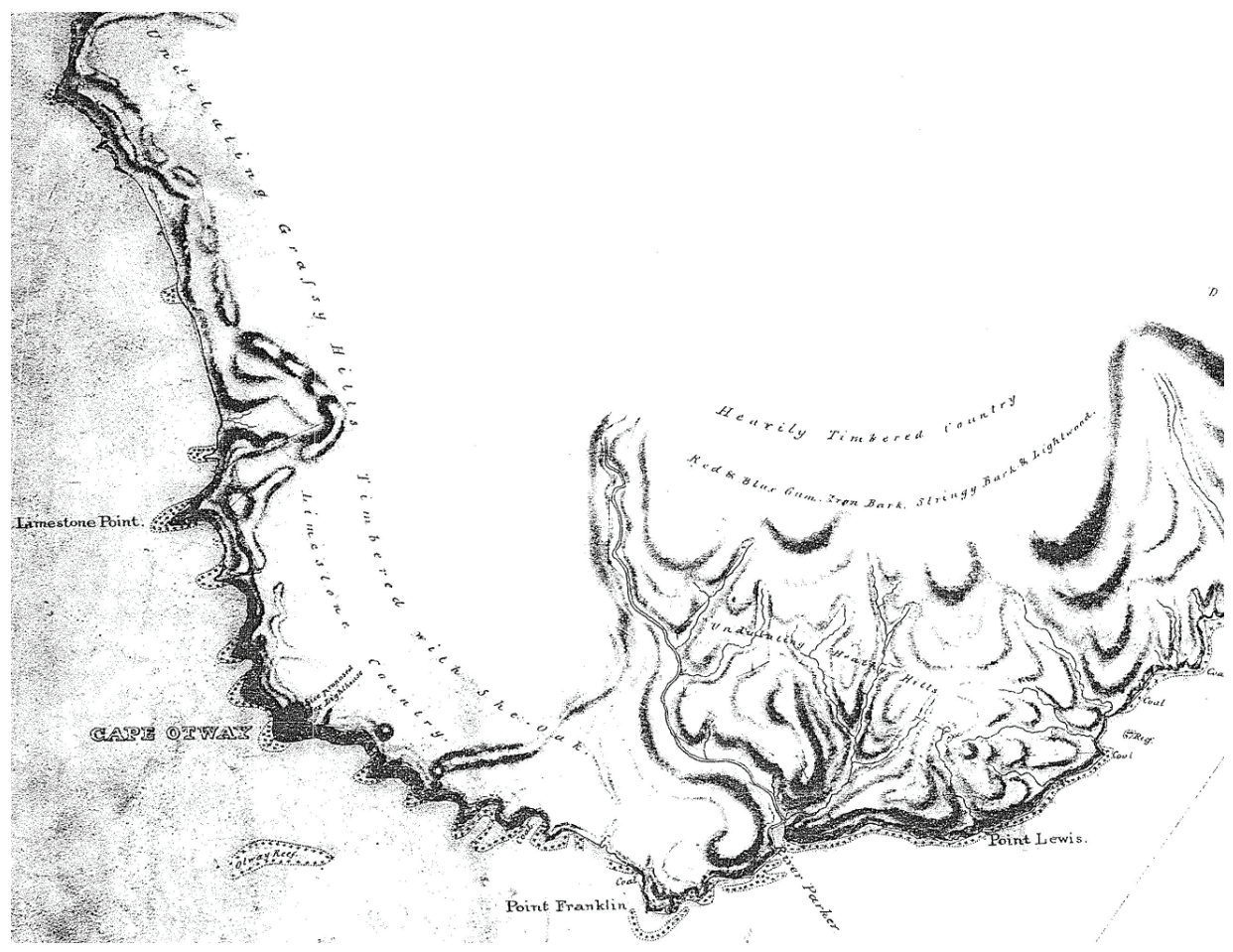

Fig 5. Portion of map drawn by GD Smythe in 1846 during the course of a survey in preparation for the construction of a lighthouse at Cape Otway.

Source: Public Record Office of Victoria, CS32-1 Aire River to Cape Patton.

Other studies of long-term environmental change in western Victoria have attributed vegetation change to anthropogenic burning. When researchers examining the Holocene sediment record at Lake Wangoom found reductions in wet forest pollen taxa and higher representations in grass species (Poaceae) they attributed change to the fact that 'effective precipitation was lower than the previous two interglacials, although it also may be a product of anthropogenic burning in the region'.$^{70}$ Favouring ridges for movement corridors across the Otway Range, it is unlikely that the Gadubanud would have deployed fire near swampy gullies found at Wyelangta and Aire Crossing. The significantly lower

68 McKenzie and Kershaw 1997: 577.

69 McKenzie and Kershaw 1997: 579.

70 Harle et al 2002: 718. 
elevation of the Chapple Vale site, and its proximity to the Gellibrand River, may have played a role in the extension of regular burning to this locale over 2000 years ago. Moreover, the timing of this change in fire pattern fits the wider sequence of Aboriginal population shift from the plains of western Victoria southward toward the forest hinterland and coast. ${ }^{71}$ This evidence points to the extension of Aboriginal fire management to the western slope of the Otway Range prior to the outright shift of population and land use practices to the coast, and certainly well before the 1420 BP first occupation date recorded at Seal Point.

In May 1847, the westward extension of the coastal survey by Robert Hoddle generated a picture of the Aire River estuary as an important site of economic activity for the Gadubanud people. Hoddle's map provides a detailed view of this settlement area and the ways in which specific land use decisions were inscribed in the land (Fig 6). Thick forests protected the northern and eastern flanks of the basin so that a large proportion of the valley was shielded from gales, and yet timber required for fuel and shelter material was kept close at hand. A well-defined boundary between an open wetland-grass shore complex and forest was undoubtedly maintained by fire. Selective burning also generated a well-indented forest edge that could serve as a habitat for animals, while the stark transition between open land and tall forests made these trees susceptible to windfalls - a useful means of toppling large trees and harvesting wood fuel in an age when only stone axes seem to have been available for this task. The patchwork mosaic encouraged through selective burning allowed for low-lying vegetation, mainly heath and grassland plains, to take hold near the coast where pedestrian movement was channelled.

Atop the outcrop that divides the estuary from the sea, a conspicuous configuration of 'good grass' and 'she-oak timber' marks a paddock used for hunting kangaroos and wallabies. When the marsupials had been lured onto the grass, the hunters would be able to spear the animals from behind the cover of she-oaks with a high probability of success. The placement of this visual barrier on elevated ground allowed for superior visibility of the surrounding terrain, while a spear thrown downhill could cover more ground and maintain a higher velocity. Even if a first attempt at spearing the animal missed its mark, the culde-sac formation chosen for this paddock allowed easy blockage of the isthmus, thereby forcing the spooked marsupials toward the marshes where their movement rate was severely constrained and they faced little chance of survival. While there may have been times when the Gadubanud lit fires at forest edges to flush out game into the paths of hunters, the use of fire to concentrate feed in paddocks of fresh grass and arrange visual barriers in the landscape allowed for a more predictable procurement of meat protein at Aire River. ${ }^{72}$

71 This sequence of land use extension from more arid inland areas to the coastal hinterland during the Holocene era is similar to that identified by Beaton in Queensland. See Beaton 1985: 1-20.

72 Bill Gammage has noted the existence of similar wallaby trap formations in Tasmania. See: Gammage 2008: 251. 


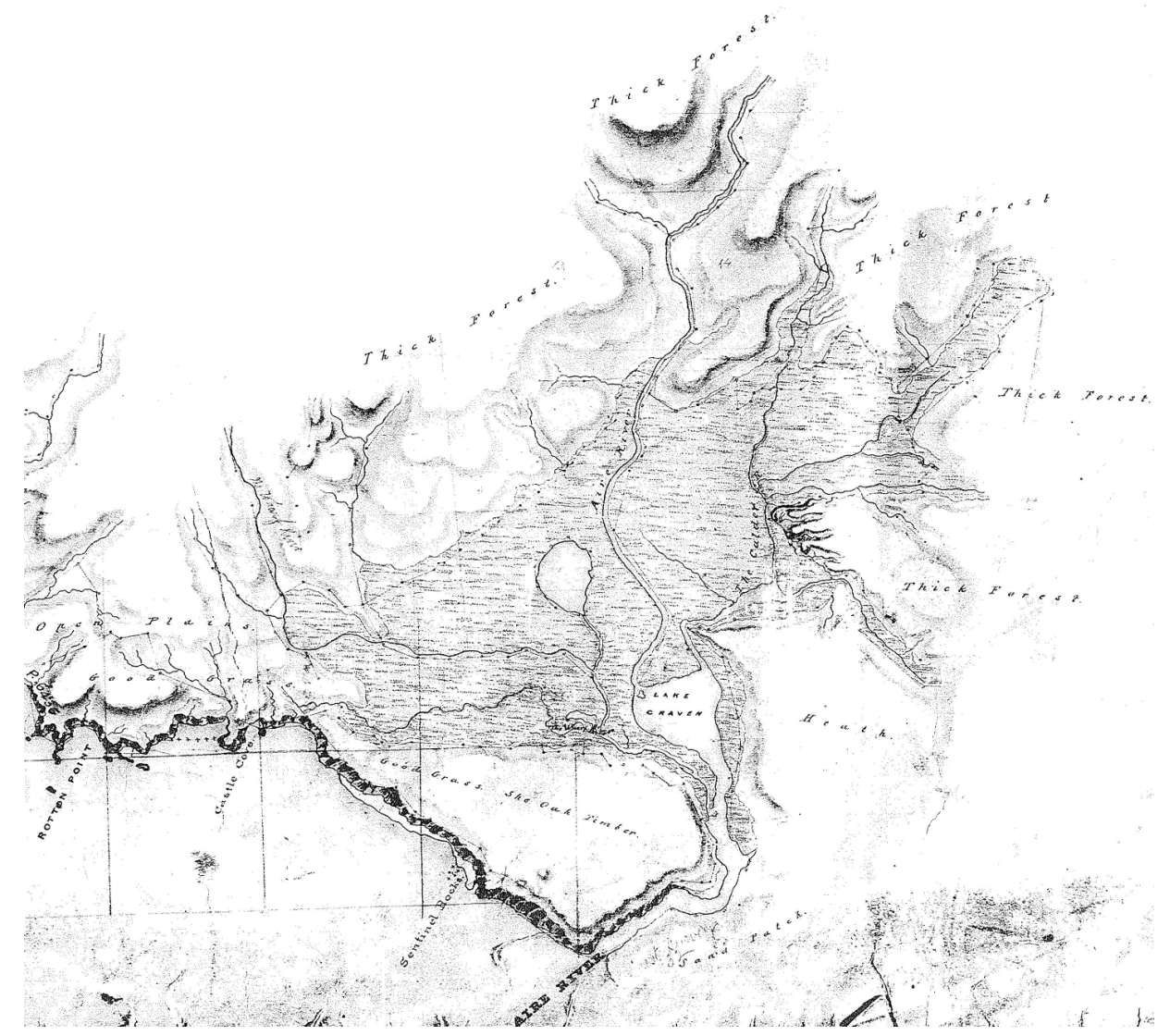

Fig 6. Portion of map drawn by Robert Hoddle in May 1847 during a coastal survey.

Source: Public Record Office of Victoria, CS33 Gellibrand River to Aire River.

Archaeological investigations at Aire River provide additional detail about Gadubanud land use and economy. In 1960, John Mulvaney excavated two rock shelters located on the north side of this outcrop, overlooking the wetland. Radiocarbon dating of charcoal deposits yielded a base occupation date ranging from 325 to $415 \mathrm{BP}$, and the rapid accumulation of debris - over six feet in depth over the period of occupation - attested to the site's popularity. ${ }^{73}$ Food debris found on site included: marine shellfish, kangaroo, rats, birds, fish, seals and abalone. This collection of remnants indicates that both coastal and estuarybased animal protein were consumed by the people residing at the Aire River, and indeed access to this wider range of foods must have heightened the appeal of this locale. In 1979, IMF Stuart followed up Mulvaney's investigation with a detailed survey of the Aire River valley. Seventy-three archaeological sites were recorded in the study, finding that 'The vast majority (64) of these sites are shell

73 Mulvaney 1961: 1-15. 
middens, but they also include 6 lithic scatters, 2 rock shelters and one isolated artefact' ${ }^{74}$ Local abundance of certain species made food procurement in the Aire River area a simple task: on La Trobe's third attempt to reach the Cape in April 1846, in the vicinity of this estuary, he and companion Henry Allan feasted on shellfish for breakfast before pushing on to their destination. ${ }^{75}$ The dietary preferences indicated by the food debris found at the Aire River archaeological dig were similar to those later exhibited at Seal Point. Subsequently, a shell midden discovered nearby in a rock shelter at Moonlight Head was found to be occupied between $1030 \mathrm{BP}$ and $180 \mathrm{BP}$. This was likely a favoured spot of the Ngarowurd gundidj clan identified by GA Robinson's Gadubanud informants. ${ }^{76}$ This archaeological find extended the known period of Aboriginal presence on this portion of the Otway coast and underscored the locale's significance as a settlement node. ${ }^{77}$

While the linkages between the Aire River and Cape Otway settlement nodes are quite clearly evinced in the coastal surveys and La Trobe's discovery of a cleared path between these two locations in 1846, it is probable that alternate movement corridors also existed in the Otway region. A more direct route connecting the people of the Aire River estuary with those of the Barwon eel marshes, circumventing Cape Otway, would have had a marked utility for the Gadubanud people. Proof that a movement corridor along the main ridge of the Otway Range may have linked the Gadubanud's northern and western clans first appeared in La Trobe's journal. Approaching the Cape from the west, his entry for 1 April 1846 noted that at Moonlight Head they came upon a trail 'where taking a native path to the left we had gone up into the ranges' ${ }^{78}$ Focused on reaching the site of the future lighthouse, La Trobe and his guide did not follow this path, instead choosing to continue along the coast to Cape Otway. In 1928, the headmaster of the school at Lavers Hill (located on the main ridge of the Otway Range, several kilometres north-east of Moonlight Head) found three stone axe heads left behind by the Gadubanud people. Reporting on this five decades after the discovery, his son noted that the artefacts were found 'beside a soak or spring $100 \mathrm{~m}$ to the north of the present Great Ocean Road' and he posited that 'people used the site because of the close proximity of water to a main trail along the ridge, making descent into the more thickly vegetated gullies unnecessary' ${ }^{79}$ Since such a path would be kept open with regular burning, the axes were not used for felling trees. More likely, they were used to notch tree trunks so that hunters could climb up and capture possums. Trail blazing had the added benefit of encouraging the growth of wattle trees, whose gum was edible. Gum was harvested during the autumn by cutting notches in bark to let the gum exude, where 'It is then gathered in large lumps, and stored for use'.$^{80}$

74 Stuart cited in Presland 1982: 4.

75 Blake 1975: 18.

76 Clark 1990: 189.

77 Richards 1998: 10-12.

78 Blake 1975: 18.

79 Douglas 1978: 222.

80 Dawson 1881: 21. 
It would have been a convenient source of sustenance during a trek over the mountains in time for the eel harvest on the north side of the range. Though there is a great deal of uncertainty regarding this particular path through the Otway forest, there are good reasons why the Gadubanud would have deposited axes at rest stops along the route between the Aire River and Barwon wetland settlement nodes.

The arrival of Europeans in the Otway region during the late 1840s led to the violent disruption of Aboriginal society and ended a long-standing system of land management. With the cessation of burning practices, surface vegetation could experience rapid 'thickening' and hinder pedestrian movement. West of Cape Otway, in April 1846 Superintendent La Trobe walked along the coast at a comfortable pace, utilising the corridors cleared by the Gadubanud. He moved quickly across this part of the region, requiring one day to reach the Gellibrand River from the Allansford station, another to walk between the Gellibrand and Johanna rivers, and a final one to reach Cape Otway. ${ }^{81}$ Only three years later, in March 1849, La Trobe and his party encountered much difficulty and marched at a considerably slower rate of movement. The landscape had not been burnt; the coastal heath grew wild, scrub took hold in places it had not been allowed previously to grow, and the vegetation thickened. The 20 to 25 miles from Apollo Bay to Cape Otway were completed with relative ease along the numerous beaches, but west of the Cape he found the travel much more strenuous:

The 40 or $50 \mathrm{~m}$. from the Cape to the Gellibrand was not achieved without a good deal of exertion, a great deal more indeed than on my first excursion, for it was found quite impossible to follow my old track, and it was not until the fifth day that we managed to fight our way through that terrible scrub, and across the precipices of Moonlight Head to the camp where the horses were awaiting us. ${ }^{82}$

In the absence of the fire-stick, the character of coastal vegetation changed rapidly. Where La Trobe had required two days to move between Cape Otway and the Gellibrand River in April 1846, only three years later the very same journey required five days. In this way, the disruption of Aboriginal society came to be expressed in the land: heath and scrub thickened, the landscape mosaic began to possess less defined boundaries between vegetation communities, well-tended environments began to build up fuel loads and wood debris. In January 1851, the Black Thursday fires swept through western Victoria and incinerated great swaths of the Otway forest.

\section{Conclusion: the reconstruction of an Aboriginal cultural landscape}

The Gadubanud people of the Otway region cared for their country and their imprint could be witnessed in the cultural landscape they created. The

81 Blake 1975: 18.

82 Blake 1975: 36. 
reconstruction of patterns of settlement, land use and communication requires a patient engagement with studies produced in a diverse set of disciplines ranging from the earth sciences to geography and archaeology. The identification of past geographical patterns allows us to piece together the decisions and constraints dealt with by generations of Aboriginal land managers that led to the development of a distinct cultural landscape. Knowledge about the landbased economy, the distribution of population and the food sources utilised by the Gadubanud people can help us protect the Aboriginal heritage of this region, guide future development away from areas of cultural and archaeological significance, and highlight the ways in which environmental constraints guided land use by Aborigines and later European occupants of the Otway region.

Fire was an important tool utilised by the Gadubanud people. It was essential for clearing movement corridors along the coast and through the forest, and allowed them to generate a complex landscape mosaic that increased the variety of foodstuffs located within walking distance of key settlement areas. For them, the Otway region was indeed a living larder. By alternating patches of high and low fire fuel this mosaic enabled the geographical spread of risk across their territory in the event of unexpected wildfire. Landscape complexity equated with food security in that the health and longevity of their people was ensured should there happen to be a localised collapse in the food resource. Working on the other side of the Bass Strait, Bill Gammage found a similar situation amongst the Aborigines of Tasmania: 'With patches spaced over many miles, their resources were more drought, flood and fire evading, more certain, than those of farmers' ${ }^{83}$

\section{Acknowledgments}

The author would like to thank Nicholas Brown, Bill Gammage, Tom Griffiths and Jock Galloway for helpful comments on an earlier version of this paper.

\section{References}

\section{Newspapers}

Geelong Advertiser

\section{Secondary sources}

Ashton, DH 1976, 'The development of even-aged stands of Eucalyptus regnans F.Muell. in Central Victoria', Australian Journal of Botany 24: 397-414.

83 Gammage 2008: 247. 
Beaton, JM 1985, 'Evidence for a coastal occupation time-lag at Princess Charlotte Bay (North Queensland) and implications for coastal colonization and population growth theories for Aboriginal Australia', Archaeology in Oceania 20(1): 1-20.

Blake, LJ (ed) 1975, Letters of Charles Joseph La Trobe, Victoriana Series No 1, Government Printer, Melbourne.

Bowdler, Sandra and Harry Lourandos 1982, 'Both sides of Bass Strait', in Coastal Archaeology in Eastern Australia, Proceedings of the 1980 Valla Conference on Australian Prehistory, Australian National University Press, Canberra.

Bride, Thomas Francis 1898, Letters from Victorian Pioneers, Heinemann, Melbourne.

Clark, Ian D 1990. Aboriginal Languages and Clans: An Historical Atlas of Western and Central Victoria, 1800-1900, Monash Publications in Geography No 37, Monash University, Melbourne.

- 1995, Scars in the Landscape: A Register of Massacre Sites in Western Victoria 1803-1859, Aboriginal Studies Press, Canberra.

- and Toby Heydon 2002, Dictionary of Aboriginal Placenames of Victoria, Victorian Aboriginal Corporation for Languages, Melbourne.

Dawson, James 1881, Australian Aborigines, George Robertson, Melbourne.

Douglas, JG 1978, 'Aborigines in the Ranges', Victorian Naturalist 95: 222-225.

Flood, Josephine 1989, Archaeology of the Dreamtime, 2nd edition, William Collins, Sydney.

Gammage, Bill 2008. 'Plain facts: Tasmania under Aboriginal management, Landscape Research 33(2): 241-254.

Gill, Edmund D 1976, 'The Aborigines and coastal processes in Western Victoria', Artefact 1(1): 31-39.

- 1978, 'Paleoecological changes in Victoria and Bass Strait as a backdrop for the marsupial megafauna and Aboriginal colonization', Artefact 3(2): 67-75.

Gott, Beth 1982, 'Ecology of root use by the Aborigines of Southern Australia', Archaeology in Oceania 17(1): 59-67.

- 2005, 'Aboriginal fire management in South-Eastern Australia: aims and frequency', Journal of Biogeography 32: 1203-1208. 
Harle, KJ et al 2002, 'A chronology for the long pollen record from Lake Wangoom, Western Victoria (Australia) as derived from Uranium/Thorium disequilibrium dating', Journal of Quaternary Science 17(7): 707-720.

Horton, David (ed) 1994, The Encyclopaedia of Aboriginal Australia, Aboriginal Studies Press (AIATSIS), Canberra.

Le Griffon, Heather 2006, Campfires at the Cross: An Account of the Bunting Dale Aboriginal Mission at Birregurra, Near Colac, Victoria 1839-1851, Australian Scholarly Publishing, North Melbourne, Victoria.

Linforth, DJ 1977, 'The climate of the Otway Region', Proceedings of the Royal Society of Victoria 89(1): 61-68.

Lissarrague, Amanda 2006, A Salvage Grammar and Wordlist of the Language from the Hunter River and Lake Macquarie, Muurrbay Aboriginal Language and Culture Cooperative, Sydney.

Lourandos, Harry 1980, 'Change or stability? Hydraulics, hunter-gatherers and population in temperate Australia', World Archaeology 11(3): 245-264.

Mannino, MA and KD Thomas 2002, 'Depletion of a resource? The impact of prehistoric human foraging on intertidal mollusc communities and its significance for human settlement, mobility and dispersal', World Archaeology 33(3): 452-474.

Massola, Aldo 1962, 'The grinding rocks at Gellibrand', Victorian Naturalist 79: 66-69.

McKenzie, G Merna and A Peter Kershaw 1997, 'A vegetation history and quantitative estimate of Holocene climate from Chapple Vale, in the Otway region of Victoria, Australia', Australian Journal of Botany 45: 565-581.

- 2000, 'The Last Glacial Cycle from Wyelangta, the Otway Region of Victoria', Australia', Palaeogeography, Palaeoclimatology, Palaeoecology 155: 177-193.

- 2004, 'A Holocene pollen record from cool temperate rainforest, Aire Crossing, the Otway Region of Victoria, Australia', Review of Palaeobotany and Palynology 132: 281-290.

Medwell, GJ 1977, 'Palaeocurrent directions in Otway Group sediments, Otway Ranges, Southeastern Australia', Proceedings of the Royal Society of Victoria 89(1): 27-50.

Meehan, Betty 1982, Shell Bed to Shell Midden, Australian Institute of Aboriginal Studies, Canberra. 
Morgan, John (ed) 1852, The Life and Adventures of William Buckley, Archibald Macdougall, Hobart.

Mulvaney, DJ 1961, 'Archaeological excavations on the Aire River, Otway Peninsula, Victoria', Proceedings of the Royal Society of Victoria 75 (1): 1-15.

Parkinson, Eleanor 2005[1863], Journal of an Expedition to Cape Otway in 1863, 2nd edition, Apollo Bay and District Historical Society Apollo Bay, Victoria.

Presland, Gary 1982, An Archaeological Survey of the Otway Forest Region, Environmental Studies Series, Ministry of Conservation, Melbourne.

Richards, Thomas 1998, A Predictive Model of Aboriginal Archaeological Site Distribution in the Otway Range, Occasional Report No 49, Aboriginal Affairs Victoria, Melbourne.

Robin, Libby and Tom Griffiths 2004, 'Environmental history in Australasia', Environment and History 10: 439-474.

Scarlett, NH 1977, 'The Aborigines of the Otway Region', Proceedings of the Royal Society of Victoria 89(1): 1-5.

Stuart, IMF 1981, 'Ethnohistory in the Otway Ranges', Artefact 6: 79-88.

Stuwe, J 1994, 'The role of fire in ground flora ecology', Victorian Naturalist 111: 93-95.

Wark, MC 1996, 'Regeneration of heath in the Northeastern Otway Ranges after the Ash Wednesday fires, February 1983', Proceedings of the Royal Society of Victoria 108: 121-141. 